\title{
VALIDATION OF A SIMPLE AND RAPID UV SPECTROPHOTOMETRIC METHOD FOR DEXAMETHASONE ASSAY IN TABLETS
}

\author{
Rossana Barcellos Friedrich, Aline Ravanello, Luiz Carlos Cichota, Clarice Madalena Bueno Rolim e \\ Ruy Carlos Ruver Beck* \\ Departamento de Farmácia Industrial, Universidade Federal de Santa Maria, Campus Camobi, 97105-900 \\ Santa Maria - RS, Brasil
}

Recebido em 20/5/08; aceito em 29/10/08; publicado na web em 5/2/09

\begin{abstract}
This work reports the validation of an analytical UV spectrophotometric method to assay dexamethasone in tablets (assay and dissolution studies). The method was linear in the range between 1 and $30 \mu \mathrm{gL}^{-1}$ presenting a good correlation coefficient $(\mathrm{r}=$ $0.9998, \mathrm{n}=7)$. Precision and accuracy analysis showed low relative standard deviation $(<2.00 \%)$ and good percentual recoveries $(95-105 \%)$. The procedure was linear, accurate, precise, and robust. The method is simple, and it has low cost. It does not use polluting reagents and can be applied in dissolution studies, being an adequate alternative to assay dexamethasone in tablets.
\end{abstract}

Keywords: dexamethasone; tablets; UV spectrophotometry.

\section{INTRODUCTION}

Dexamethasone, $9 \alpha$-fluoro-16 $\alpha$-methyl-11 $\beta, 17 \alpha, 21$-trihydroxy1,4-pregnadiene-3,20-dione, is a synthetic derivative of the glucocorticoid hydrocortisone that has a long history of use in humans. ${ }^{1}$ It is a white to practically white, odorless, crystalline powder, stable in air, practically insoluble in water, slightly soluble in methylene chloride, and sparingly soluble in ethanol. ${ }^{2}$ It is found in the pharmaceutical market in form of tablets, aerosol, creams and ophthalmic suspensions. The empirical formula is $\mathrm{C}_{22} \mathrm{H}_{29} \mathrm{FO}_{5}$ and the structural formula is represented in Figure 1.

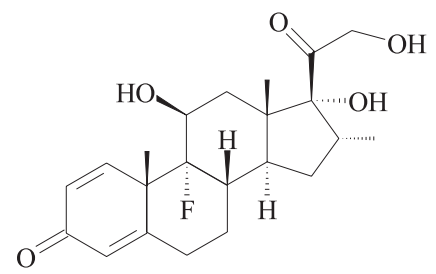

Figure 1. Chemical structure of dexamethasone

It is widely used in clinical practice because of its anti-inflammatory and immunosuppressive activities ${ }^{3}$, being employed on the treatment of arthritis, asthma, eye inflammations and illnesses of collagen, as well as on the prevention of undesirable immune reactions. ${ }^{4}$

Many methods have been employed to assay dexamethasone in biological materials such as plasma, serum, urine, tears, and hair ${ }^{5-9}$ as well as pharmaceutical formulations. ${ }^{10-17}$ Besides, methods for the quantification of dexamethasone in association to other drugs have also been reported. ${ }^{16,18-20}$

The predominant method in pharmaceutical steroid analyses is the reversed phase HPLC with UV detection, but chromatographic techniques are time consuming, costly and require expertise. ${ }^{21} \mathrm{Sci}-$ entific literature does not show any validation of UV spectrophotometric method for the quantitative determination of dexamethasone in tablets.

\footnotetext{
*e-mail: ruybeck@smail.ufsm.br
}

In the methods described in official compendiums, ${ }^{17}$ dexamethasone can be quantified in its diverse pharmaceutical forms using visible spectrophotometry (topical aerosol and gel) or by HPLC (elixir, injectable, ophthalmic suspensions and tablets). In the same way, British Pharmacopoeia 2008 describes the quantification of dexamethasone tablets by HPLC. ${ }^{2}$

Regarding the drug assay during the dissolution test of dexamethasone tablets, USP 30 described a visible spectrophotometric method to quantify dexamethasone dissolved in the medium $(\mathrm{HCl}$ $0.1 \mathrm{~N}$ ). This method is carried out by the extraction of the drug with chloroform and later the solution must remain in contact with blue tetrazolium for the occurrence of the color reaction during $90 \mathrm{~min} .{ }^{17}$

In order to obtain a simple, cheaper, faster, less environmental toxic method for the quantitative assay of dexamethasone in tablets (drug assay and dissolution test), this study aimed to validate a spectrophotometric method, employing mainly distilled water, as solvent. The validation procedure was carried out according to the ICH guideline and the parameters evaluated were specificity, linearity, range, precision, accuracy, and robustness. ${ }^{22}$

\section{EXPERIMENTAL}

\section{Materials}

Dexamethasone used as a reference substance was obtained from Henrifarma (São Paulo, Brazil). The tablets were purchased locally and were demanded to contain $4.0 \mathrm{mg}$ dexamethasone. Methanol was of analytical grade and used as received.

\section{Preparation of stock standard solution}

Stock standard solution $\left(0.5 \mathrm{mg} \mathrm{mL}^{-1}\right)$ was prepared dissolving 25 $\mathrm{mg}$ of dexamethasone reference substance, accurately weighed, in a mixture of methanol:water $(1: 2)$ in a $50 \mathrm{~mL}$ volumetric flask.

\section{Preparation of sample solutions}

Twenty tablets were weighed and the average weight was calculated for each one. Tablets were crushed to a fine powder. Amounts equi- 
valent to $2.0 \mathrm{mg}$ dexamethasone from each one were transferred to 25 $\mathrm{mL}$ volumetric flasks and $15 \mathrm{~mL}$ of diluted methanol (methanol:water $1: 2 \mathrm{v} / \mathrm{v}$ ) was added. The flasks were shaken ultrasonically for $15 \mathrm{~min}$ and the solutions were then diluted to volume with diluted methanol. Solutions were filtered through quantitative filter paper (Sartorius, Germany). Subsamples of these solutions were diluted with distilled water to obtain final concentrations of $20 \mu \mathrm{g} \mathrm{mL} \mathrm{L}^{-1}$.

\section{Spectrophotometric method}

An UV spectroscopic scanning run (200-400 nm) was carried out with the reference solution to select the best UV wavelength $\left(\lambda_{\max }\right)$ for detection of dexamethasone in an aqueous solution (Milton Roy Spectrophotometer, model 3n28053002, New York, USA.). The analyses were carried out using distilled water as blank.

\section{Specificity}

Specificity was evaluated by analyzing solutions containing all the components of the dexamethasone tablets, excepting the drug (placebo). The system response was examined for the presence of interference or overlaps with dexamethasone responses at $241 \mathrm{~nm}$.

\section{Linearity, limits of detection (LOD) and quantification (LOQ)}

Three series (analytical curves) of standard solutions of dexamethasone $\left(1,5,10,15,20,25\right.$ and $\left.30 \mu \mathrm{gL}^{-1}\right)$ were prepared by the dilution of the stock standard solution in distilled water. Absorbances were measured, in triplicate, at $241 \mathrm{~nm}$. Limits of detection (LOD) and quantification (LOQ) were calculated directly from the calibration plot. LOD and LOQ were calculated as $3.3 \sigma / \mathrm{S}$ and $10 \sigma / \mathrm{S}$, respectively, where $\sigma$ is the standard deviation of intercept and $S$ is the slope of the calibration plot. ${ }^{22}$

\section{Precision}

Intra-day precision (repeatability) was evaluated by measuring, in triplicate, six different samples at the same concentration $(20.0 \mu \mathrm{g}$ $\mathrm{mL}^{-1}$ ), under the same experimental conditions and on the same day, according to the sample preparation described previously. Inter-day precision (intermediate precision) was calculated from results obtained by the analysis of samples with the same concentration $(20.0 \mu \mathrm{g}$ $\mathrm{mL}^{-1}, \mathrm{n}=3$ ) on two different days (inter-day precision).

\section{Accuracy}

The accuracy was evaluated assaying, in triplicate, samples of known concentration with the addition of different concentrations of the chemical substance of reference (2, 3, and $4 \mu \mathrm{g} \mathrm{mL}^{-1}$ in water). The recovery $(\%)$ of the pure drug added was calculated as recovery $(\%)=\left[\left(\mathrm{C}_{\mathrm{t}}-\mathrm{C}_{\mathrm{a}}\right) / \mathrm{C}_{\mathrm{s}}\right] \times 100$, where $\mathrm{C}_{\mathrm{t}}$ is the total drug concentration measured after standard addition; $\mathrm{C}_{\mathrm{s}}$, drug concentration in the formulation sample; $\mathrm{C}_{\mathrm{a}}$, drug concentration added to the formulation. ${ }^{22,23}$

\section{Robustness}

Robustness of the proposed method was determined by the analysis of samples and standard solutions $\left(20 \mu \mathrm{gL}^{-1}\right)$ at different wavelengths.

\section{Dissolution test}

The dissolution test of dexamethasone tablets was carried out according to the method described in the USP $30 .{ }^{17}$ Tests were car- ried out using a dilute hydrochloric acid solution (1 in 100) at $37 \pm$ $0.5^{\circ} \mathrm{C}$, with 100 rotations per minute using the apparatus I (basket). After $45 \mathrm{~min}$, samples were removed, filtered, and the amount of dexamethasone determined by the UV spectrophotometer method proposed in this study.

\section{RESULTS AND DISCUSSION}

The aim of this work was to validate a simple, rapid and less environmental toxic method to assay dexamethasone in tablets by UV spectrophotometry. This way, we choose a diluted methanol solution (methanol:water 1:2 v/v) as the first diluting solvent and distilled water for the subsequent dilutions. Initially, an UV spectroscopic scanning run allowed selecting the wavelength of $241 \mathrm{~nm}$ as the best for the detection of dexamethasone in the standard solution as well as in sample solutions.

In order to verify the absence of excipients on the analysis of dexamethasone in tablets, we carried out the analysis of a sample prepared with all the excipients present in the tablets, but without the drug (placebo). Absorption spectra did not show any potential interference of the tablet excipients at $241 \mathrm{~nm}$.

A linear relationship was found between the absorbance at 241 $\mathrm{nm}$ and the concentration of dexamethasone in the range of 1.0 to $30.0 \mu \mathrm{g} \mathrm{mL}^{-1}$. The correlation coefficient was 0.9998 indicating good linearity $(r>0.999)$. The representative linear equation was $y=0.0390 x+0.0019$, calculated by the least squares method. The limit of quantification (LOQ) was found as $1.56 \mu \mathrm{g} \mathrm{mL}$. The limit

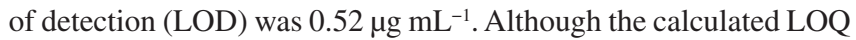
was $1.56 \mu \mathrm{g} \mathrm{mL}^{-1}$ it was possible to include the concentration of $1.00 \mu \mathrm{g} \mathrm{mL}^{-1}$ in the analytical curve, which showed relative standard deviation below $1.50 \%$.

The intra-day and inter-day relative standard deviation (R.S.D.) values obtained by the proposed method were found to be lower than $2.0 \%$. The accuracy of the methods expressed as recovery (\%) was between 101 and $103 \%$. Results are given in Tables 1 and 2, respectively.

In addition, the reliability of the proposed method was also evaluated by means of the robustness test (Table 3). The absorbance of standard and sample solutions was determined at the UV wavelength used in this study $\left(\lambda_{\max }\right) \pm 4 \mathrm{~nm}$. No significant difference could be observed in the results found out.

Table 1. Intra-day (repeatability) and inter-day (intermediate precision) precision of the method (theoretical concentration: $20 \mu \mathrm{g} \mathrm{mL}^{-1}$ )

\begin{tabular}{lccc}
\hline Precision & $\begin{array}{c}\text { Experimental } \\
\text { concentration }\left(\mu \mathrm{g} \mathrm{mL}^{-1}\right)\end{array}$ & $\begin{array}{c}\text { Mean } \\
\text { recovery }(\%)\end{array}$ & $\begin{array}{c}\text { RSD } \\
(\%)\end{array}$ \\
\hline Intra-day $(\mathrm{n}=6)$ & $20.71 \pm 0.29$ & 103.55 & 1.40 \\
Inter-day & & & \\
Day 1 $(\mathrm{n}=3)$ & $20.61 \pm 0.36$ & 103.05 & 1.75 \\
Day 2 $(\mathrm{n}=3)$ & $20.57 \pm 0.26$ & 102.85 & 1.27 \\
Mean $\pm \mathrm{SD}(\mathrm{n}=6)$ & $20.59 \pm 0.03$ & 102.95 & 0.14 \\
\hline
\end{tabular}

Table 2. Results from accuracy of the method

\begin{tabular}{lccc}
\hline $\begin{array}{l}\text { Sample } \\
\left(\mu \mathrm{g} \mathrm{mL} \mathrm{m}^{-1}\right)\end{array}$ & $\begin{array}{c}\text { Standard added } \\
\left(\mu \mathrm{g} \mathrm{mL}^{-1}\right)\end{array}$ & $\begin{array}{c}\text { Found } \\
\left(\mu \mathrm{g} \mathrm{mL}^{-1}\right)\end{array}$ & $\begin{array}{c}\text { Accuracy } \\
(\%)\end{array}$ \\
\hline & 2 & $19.25 \pm 0.56$ & 102.07 \\
$16.90 \pm 0.11$ & 3 & $20.36 \pm 0.24$ & 102.72 \\
& 4 & $21.24 \pm 0.14$ & 102.01 \\
Mean recovery $(\%)$ & & & $102.27 \pm 0.39$ \\
\hline
\end{tabular}


Table 3. Robustness of the method at three different UV wavelengths $(241 \pm 4 \mathrm{~nm})$

\begin{tabular}{|c|c|c|c|}
\hline \multirow[b]{2}{*}{$\begin{array}{l}\text { Wavelength } \\
(\mathrm{nm})\end{array}$} & \multicolumn{2}{|c|}{ Absorbance } & \multirow[b]{2}{*}{$\begin{array}{c}\text { Drug content } \\
(\%)\end{array}$} \\
\hline & $\begin{array}{l}\text { Sample solution } \\
\left(20 \mu \mathrm{g} \mathrm{mL}^{-1}\right)\end{array}$ & $\begin{array}{l}\text { Standard solution } \\
\qquad\left(20 \mu \mathrm{g} \mathrm{mL}^{-1}\right)\end{array}$ & \\
\hline 237 & $0.763 \pm 0.001$ & $0.768 \pm 0.004$ & 99.34 \\
\hline 241 & $0.804 \pm 0.002$ & $0.805 \pm 0.003$ & 99.88 \\
\hline 245 & $0.781 \pm 0.001$ & $0.793 \pm 0.003$ & 98.49 \\
\hline
\end{tabular}

After the validation of the UV spectrophotometric we carried out a dissolution test to demonstrate the feasibility to apply this alternative method to the quantitative analysis of the dissolved dexamethasone in the dissolution media. The results obtained are showed in Table 4 and were in accordance with the official specifications. ${ }^{17}$

Table 4. Results from the drug assay in the dissolution test

\begin{tabular}{lc}
\hline Vessel & Drug concentration $(\%)$ \\
\hline 1 & 107.18 \\
2 & 105.92 \\
3 & 104.32 \\
4 & 107.82 \\
5 & 105.60 \\
6 & 104.64 \\
\hline Mean \pm SD & $105.91 \pm 1.38$ \\
DPR $(\%)$ & 1.30 \\
\hline
\end{tabular}

In conclusion, the method developed in this study represents an alternative to assay dexamethasone in tablets being specific, linear, precise and accurate in the concentration range between 1 and $30 \mu \mathrm{g}$ $\mathrm{mL}^{-1}$. The method reported here was adequately applied to the quantification of dexamethasone in the dissolution medium, widely used in routine of quality control laboratories. It has cheap, fast and simpler sample preparation, without chloroform extraction or evaporation steps. Furthermore it allows reducing the volume of dangerous residues promoting benefits to the public health and the environment.

\section{REFERENCES}

1. Katzung, B. G.; Farmacologia Básica e Clínica, 6ª ed., Guanabara Koogan S.A.: Rio de Janeiro, 1998.

2. http://www.pharmacopoeia.co.uk, acessada em Abril 2008.

3. Hang, H. P.; Dale, M. M.; Ritter, J. M.; Moore, P. K.; Farmacologia, $5^{\text {a }}$ ed., Elsevier: São Paulo, 2003.

4. Gilman, A. G.; Rall, T. W.; Nies, A.; Taylor, P.; As bases farmacológicas da terapêutica, $8^{\text {a }}$ ed., Guanabara Koogan S.A.: Rio de Janeiro, 1991.

5. Baeyens, V.; Varesio, E.; Veuthey, J. L.; Gurny, R.; J. Chromatogr., B: Anal. Technol. Biomed. Life Sci. 1997, 692, 222.

6. Cirimele, V.; Kintz, P.; Dumestre, V.; Goullé, J. P.; Ludes, B.; Forensic Sci. Int. 2000, 107, 381.

7. Taylor, R. L.; Grebe, S. K.; Singha, R. J.; Clin. Chem. (Washington, DC, U. S.) 2004, 50, 2345.

8. Zurbonsen, K.; Bressolle, F.; Solassol, I.; Aragon, P. J.; Culine, S.; Pinguet, F.; J. Chromatogr., B: Anal. Technol. Biomed. Life Sci 2004, $804,421$.

9. Damonte, G.; Salis, A.; Rossi, L.; Magnani, M.; Benatti, U.; J. Pharm. Biomed. Anal. 2007, 43, 376.

10. Beck, R. C. R.; Acta Farm. Bonaerense 2001, 20, 127.

11. Collado, M. S.; Robles, J. C.; Zan, M. D.; Cámara, M. S.; Mantovani, V. E.; Goicoechea, H. C.; Int. J. Pharm. 2001, 229, 205.

12. Spangler, M.; Mularz, E.; Chromatographia 2001, 54, 329.

13. Garcia, C. V.; Breier, A. R.; Steppe, M.; Schapoval, E. E. S.; Oppe, T. P.; J. Pharm. Biomed. Anal. 2003, 31, 597.

14. Peña-García-Brioles, D.; Gonzalo-Lumbreras, R.; Izquierdo-Hornillos, R.; Santos-Montes, A.; J. Pharm. Biomed. Anal. 2004, 36, 65.

15. Hashem, H.; Jira, T.; Chromatographia 2005, 61, 133.

16. Baranowska, I.; Markowski, P.; Baranowski, J.; Anal. Chim. Acta 2006, $570,46$.

17. The United States Pharmacopeia/The National Formulary; 30 ed, Pharmacopoeial Convention: Rockville, 2006.

18. Gallego, J. M. L.; Arroyo, J.; Anal. Chim. Acta 2001, 437, 247.

19. Gallego, J. M. L.; Arroyo, J.; J. Pharm. Biomed. Anal. 2002, 30, 1255.

20. Milojevic, Z.; Agbaba, D.; Eric, S.; Borojevic, D. B.; Ristic, P.; Solujic, M.; J. Chromatogr., A 2002, 949, 79.

21. Görög, S.; Anal. Sci. 2004, $20,767$.

22. ICH - Harmonised Tripartity Guideline; Validation of Analytical Procedures: Text and Methodology Q2(R1). IFPMA:Geneva, 2005.

23. Agência Nacional de Vigilância Sanitária (ANVISA); Resolução RE 899 de 29 de maio de 2003 - Guia para validação de métodos analíticos e bioanalíticos, Diário Oficial da União: Brasília, 2003 